\title{
PERUBAHAN STRATEGI DIPLOMASI AMERIKA SERIKAT TERHADAP KONFLIK INTERNAL SURIAH PADA TAHUN $2013-2014$
}

\author{
Syuryansyah, Andrialius Feraera \\ Program Studi Administrasi Publik \\ FISIPKUM Universitas Serang Raya
}

*Coressponding Author, email : syuryansyah.syh@gmail.com

\begin{abstract}
Abstrak
Artikel ini menjelaskan alasan atau motif di balik adanya perubahan strategi diplomasi dari hard power menjadi soft power yang dilakukan oleh Amerika Serikat dalam Konflik Internal Suriah. Perubahan strategi diplomasi tersebut dilakukan setelah melakukan kalkulasi untung rugi dimana strategi soft power dipertimbangkan lebih menguntungkan bagi Amerika Serikat baik dari segi ekonomi dan politik daripada menggunakan strategi diplomasi hard power sebagai sarana diplomasi dalam konflik internal yang terjadi di Suriah. Amerika Serikat kemudian mengubah strategi diplomasinya menjadi soft power yang berimplikasi pada ditariknya seluruh armada kapal perang Amerika Serikat dari Perairan Mediterania.
\end{abstract}

Kata Kunci : Strategi, Diplomasi, Konflik, Hard Power, Soft Power, Amerika Serikat, Suriah.

\begin{abstract}
This article explains the reasons or motives behind the change in diplomatic strategy from hard power to soft power carried out by the United States in Syria's Internal Conflict. The change in diplomacy strategy was made after calculating the profit and loss in which the soft power strategy was considered more profitable for the United States both in economic and political terms than using the hard power diplomacy strategy as a means of diplomacy in the internal conflict that occurred in Syria. The United States then changed its diplomatic strategy to soft power which had implications for the withdrawal of the entire United States warship from Mediterranean waters.
\end{abstract}

Keywords: Strategics, Diplomacy, Conflict, Hard Power, Soft Power, United States, Syria 
Jurnal Administrasi Negara

ISSN : 2598-4039 (Online)

ISSN : 2302-2231 (Print)

\author{
Syuryansyah, Andrialius Feraera \\ Universitas Serang Raya
}

\section{PENDAHULUAN}

Untuk merespon meningkatnya eskalasi konflik internal yang terjadi di Suriah dan adanya indikasi penggunaan senjata kimia berbahaya oleh rezim Assad, pada pertengahan 2013 lalu, Amerika Serikat melibatkan diri dalam pergolakan internal Suriah (Islam Times, 2014). Keterlibatan Amerika Serikat dalam konflik internal Suriah ini diklaim dilakukan atas dasar kemanusiaan untuk menghentikan tindakan pemerintah Suriah yang telah menggunakan senjata kimia berbahaya untuk memadamkan aksi demonstrasi di Suriah (BBC, 2013). Akibat adanya penggunaan gas kimia berbahaya tersebut, lebih dari 3000 orang warga sipil tercatat menderita neurotoxic symptoms. Sejak 2013 silam, Dewan Keamanan PBB menyatakan bahwa konflik berkepanjangan di Suriah telah menyebabkan lebih dari 70.000 masyarakat tewas terbunuh dan ribuan lainnya kehilangan sanak keluarga, harta dan tempat tinggal sehingga terpaksa mengungsi ke beberapa negara tetangga terdekat (Public Broadcasting Service, 2013).

Penggunaan senjata kimia berbahaya tersebut dianggap telah melewati 'garis merah' dan Amerika Serikat perlu mengambil sikap yang tegas dalam merespon bahaya terhadap kemanusiaan tersebut. Presiden Barack
Obama kemudian menggagas rencana untuk melakukan invasi militer terhadap Suriah. Amerika Serikat lalu menerjunkan dan mengoperasikan kapal - kapal induknya yang dilengkapi dengan peralatan tempur canggih dan berteknologi tinggi di sekitar kawasan perairan mediterania yang tak jauh dari perbatasan laut Suriah (Kompasiana, 2013).

Namun dalam perkembangannya, pada september 2013 silam, Amerika Serikat mengubah strategi diplomasinya dalam mengatasi konflik yang terjadi di Suriah. Perubahan strategi ini dilakukan setelah Amerika Serikat memutuskan untuk menyepakati opsi diplomatik yang ditawarkan oleh Rusia yang berdiri di pihak Suriah (VoA , 2013). Dengan dicapainya opsi diplomatik tersebut, Amerika Serikat sepakat untuk menarik seluruh armada militernya dari Suriah setelah Suriah bersedia menyerahkan seluruh pasokan senjata kimianya di bawah pengawasan internasional. Akibatnya, seluruh armada militer Amerika Serikat seperti kapal induk USS Nimitz, USS Graveley, USS Harry S Truman telah diperintahkan untuk kembali ke pangkalannya di West Coast, Amerika Serikat (Detik News, 2013).

Keputusan Amerika Serikat yang mengubah strategi diplomasinya dari 
Jurnal Administrasi Negara

ISSN : 2598-4039 (Online)

ISSN : 2302-2231 (Print)
Syuryansyah, Andrialius Feraera

Universitas Serang Raya hard power menjadi soft power tersebut terbilang cukup kontradiktif dengan motif awal Amerika Serikat yang mengklaim bahwa intervensi militer dilakukan untuk mengatasi krisis kemanusiaan yang tengah terjadi di Suriah. Krisis kemanusiaan di Suriah masih terus berlangsung hingga saat ini bahkan jauh lebih parah daripada sebelumnya. Perubahan strategi diplomasi yang dilakukan oleh Amerika Serikat dianalisis tak menyelesaikan problem kemanusiaan di Suriah karena notabenenya, krisis kemanusiaan tak semata - mata disebabkan oleh adanya penggunaan senjata kimia berbahaya oleh Pemerintah Suriah. Krisis kemanusiaan jauh lebih parah terjadi karena adanya konflik berkepanjangan antara pemerintah, kubu oposisi dan adanya intervensi aktor eksternal termasuk kelompok radikal islam yang telah menyebabkan konflik berubah kearah Proxy War, yang pada akhirnya menjatuhkan korban di pihak masyarakat sipil (New Yorker News, 2013).

Strategi adalah pendekatan secara keseluruhan yang berkaitan dengan pelaksanaan suatu gagasan, perencanaan, dan eksekusi sebuah aktivitas dalam kurun waktu tertentu. Strategi juga dimengerti sebagai perencanaan tingkat tinggi untuk mencapai sebuah atau beberapa tujuan di bawah suatu kondisi yang tak menentu (Rumelt, 2011). Strategi terdiri atas susunan koordinasi tim kerja, tema, identifikasi faktor pendukung yang sesuai dengan prinsip-prinsip pelaksanaan gagasan secara rasional, efisien dalam pendanaan maupun pelaksanaan aktivitas, dan memiliki taktik untuk mencapai tujuan secara efektif. Strategi dibedakan dengan taktik yang memiliki ruang lingkup yang lebih sempit dan waktu yang lebih singkat dimana taktik adalah bagian dari sebuah strategi. Taktik merupakan langkah langkah dalam menjalankan strategi. Secara definitive, taktik dimaknai sebagai sebuah tindakan implementasi konseptual atas sebuah aksi yang spesifik (Business Dictionary, 2010). Amerika Serikat pada awalnya menjalankan strategi diplomasi hard power, dengan berwacana untuk melakukan invasi militer dengan mengoperasikan kapal - kapal induknya yang dilengkapi dengan pasukan bersenjata lengkap di sekitar perairan Mediterania. Namun dalam perkembangannya, Amerika Serikat melakukan perubahan strategi diplomasi ke arah yang lebih soft dengan membatalkan invasi militernya dan memilih melakukan diplomasi di atas meja perundingan atas prakarsa Rusia yang berada di pihak Suriah. 
Jurnal Administrasi Negara

ISSN : 2598-4039 (Online)

ISSN : 2302-2231 (Print)
Syuryansyah, Andrialius Feraera

Universitas Serang Raya
Hard Power dikembangkan dalam bentuk kekuatan koersif, penggunaan kekerasaan, ancaman penggunaan kekerasan ataupun kekuatan militer / fisik maupun sanksi ekonomi (Kementerian Pertahanan, 2014). Hard power kerap kali dilakukan dengan tindakan yang ofensif dan agresif dan akan menjadi sangat efektif ketika tindakan ofensif tersebut ditujukan kepada political unit lain yang lebih lemah dari segi militer maupun ekonomi (Nye, Propaganda Isn't the Way: Soft Power, 2003). Joseph Nye menyebutkan penggunaan istilah stick dan carrot dalam menggambarkan konsep hard power maupun soft power. Tindakan rewards dalam bentuk berbagai kebijakan melalui pendekatan yang lebih soft tersebut dikenal dengan istilah carrot. Sedangkan istilah stick dikenal sebagai pendekatan hard power dengan penggunaan kebijakan kebijakan diplomasi koersif untuk memberikan punishment dalam bentuk sanksi ekonomi maupun invasi militer (Nye, 2004).

Pada awalnya Amerika Serikat melibatkan diri dalam konflik internal Suriah dengan menggunakan strategi diplomasi hard power melalui adanya kebijakan untuk melakukan invasi militer di Suriah. Presiden Barrack Obama menerjunkan armada - armada militernya dan mengoperasikan kapal - kapal induk militer berkapasitas tekhnologi tempur canggih di sekitar perairan mediterania yang mendekati wilayah perairan Suriah. Amerika Serikat dalam hal ini diindikasikan menggunakan jenis stick melalui strategi diplomasi hard power dalam rangka memberi punishment terhadap Suriah, karena menurut Amerika Serikat, Pemerintah Suriah telah menggunakan senjata kimia berbahaya hingga melewati 'red line' untuk memadamkan aksi perlawanan di Suriah hingga mengakibatkan jatuhnya korban jiwa secara massal dari berbagai golongan terutama warga sipil. Selain sebagai punishment, penggunaan strategi diplomasi hard power oleh Amerika Serikat dilakukan sebagai bentuk ancaman untuk mempengaruhi kebijakan dan tindakan Pemerintah Suriah sehingga pada akhirnya, dengan adanya penggunaan pendekatan koersif melalui ancaman invasi militer yang akan dijalankan oleh Amerika Serikat, Pemerintah Suriah akan merubah arah kebijakannya menjadi sejalan dengan keinginan Amerika Serikat.

Soft power menurut Joseph Nye dideskripsikan sebagai kemampuan untuk mengajak ataupun menarik dengan menggunakan pendekatan kooptasi yang lembut daripada mengedepankan penggunaan kekerasan yang koersif ataupun pemberian 
Jurnal Administrasi Negara

ISSN : 2598-4039 (Online)

ISSN : 2302-2231 (Print)

\author{
Syuryansyah, Andrialius Feraera \\ Universitas Serang Raya
}

finansial sebagai tindakan persuasif (Foreign Policy, 2006). Berbeda

dengan hard power, penggunaan soft power lebih mengarah kepada tindakan penarikan ataupun pendekatan secara positif dan persuasif untuk mencapai tujuan dari kebijakan luar negeri suatu negara. Joseph Nye menjelaskan bahwa tindakan seduktif melalui soft power dapat menjadi lebih efektif daripada penggunaan pendekatan koersif melalui hard power (S.Nye, 2011).

Dalam kasus ini, dapat dispesifikasikan bahwa soft power dimaknai sebagai tindakan Amerika Serikat yang lebih mengedepankan kesepakatan diatas meja perundingan dengan Suriah. Amerika Serikat mengubah strategi diplomasinya dari hard power menjadi soft power seiring Amerika Serikat mencapai kata sepakat dalam negosiasi melalui jalur diplomasi damai dengan Suriah yang diprakarsai oleh Rusia. Amerika Serikat dalam negosiasi terkait sepakat untuk membatalkan invasi militernya terhadap Suriah apabila Suriah bersedia menyerahkan seluruh pasokan senjata kimianya di bawah pengawasan internasional hingga pertengahan 2014.

Teori Model Aktor Rasional berasumsi bahwa negara adalah satu satunya aktor dalam politik dunia. Model ini mempunyai prinsip "maximize their gains, minimize their loses" (Graham T.Allison, 1963). Teori ini menekankan bagaimana negara sebagai aktor tunggal dalam proses pengambilan keputusan, melakukan kalkulasi untung rugi terhadap setiap opsi/alternatif tindakan yang akan dipilih dan dilakukannya. Apabila negara dihadapkan pada dua opsi dan negara diposisikan harus memilih salah satu diantara dua opsi tersebut, maka negara sebagai aktor rasional, akan memilih opsi yang paling menguntungkan atau memilih opsi dengan resiko kerugian yang paling minimal.

Dalam kasus ini, Amerika Serikat dihadapkan pada kondisi dilematis, apakah memutuskan untuk menggunakan strategi hard powernya dengan menginvasi Suriah, atau menggunakan strategi soft power dengan mengutamakan negosiasi di atas meja perundingan dengan pihak Suriah. Hard power beresiko merugikan Amerika Serikat baik dari segi ekonomi maupun politik. Kerugian dari segi ekonomi yang beresiko akan ditanggung Amerika Serikat apabila strategi hard power digunakan yakni berupa membengkaknya biaya yang akan dikeluarkan oleh Amerika Serikat. Pada Perang Afghanistan maupun Irak, Harvard University's Kennedy School of Government mencatat bahwa Amerika Serikat telah mengeluarkan biaya 
Jurnal Administrasi Negara

ISSN : 2598-4039 (Online)

ISSN : 2302-2231 (Print)
Syuryansyah, Andrialius Feraera

Universitas Serang Raya hingga USD 6 Triliun (Global Research, 2015). Besarnya biaya perang tersebut bahkan beresiko menjadi lebih besar lagi apabila Amerika Serikat memutuskan untuk menggunakan strategi hard power dalam konflik internal Suriah ini, mengingat konflik Suriah melibatkan multi aktor yang begitu beragam dan sulit untuk diatasi. Tak hanya itu, penggunaan strategi hard power juga beresiko menyebabkan tingginya korban jiwa yang berjatuhan dari pihak Amerika Serikat mengingat pada perang sebelumnya baik di Irak maupun di Afghanistan, pasukan Amerika Serikat yang menjadi korban jiwa mencapai angka hingga ribuan jiwa (Military Factory, 2014).

Sehubungan dengan hal tersebut, konflik internal Suriah merupakan konflik berkepanjangan yang sulit untuk terselesaikan. Cukup sulit untuk memprediksi kapan konflik akan berakhir. Penggunaan hard power untuk menghadapi target yang besar dalam konflik yang meluas dan berkepanjangan dalam waktu yang lama beresiko tinggi merugikan Amerika Serikat dalam segi politik. Dalam konflik tersebut telah muncul semakin banyak aktor dan faksi politik. Semakin bertambahnya jumlah faksi politik di Suriah menyebabkan semakin tidak jelasnya musuh bagi Amerika Serikat. Hal ini terjadi karena adanya peningkatan angka pertumbuhan kubu - kubu oposisi dan kelompok kelompok baru pendukung pemerintah yang menyebabkan munculnya semakin banyak aktor yang terlibat dalam konflik tersebut. Beberapa kubu - kubu utama di Suriah yakni Syrian Army, Free Syrian Army, Islamic Front, Jabhat Al Nusra yang terhubung dengan Al Qaeda, Hizbullah, Kurdi serta Islamic State of Iraq and the Levant (ISIL) (ABC News, 2014).

Selain itu, Amerika Serikat juga beresiko mendapat kecaman dan kritik dari dunia internasional terutama kelompok kemanusiaan apabila melakukan invasi militer karena upaya hard power tersebut justru bertentangan dengan image yang selama ini dibawa oleh Amerika Serikat yakni "peace" dan "demokrasi" terlebih dalam kasus ini proposal Amerika Serikat untuk menginvasi Suriah telah ditentang oleh Prancis maupun Inggris sebagai sekutu terdekat Amerika Serikat. Dalam internal Amerika Serikat sendiri, upaya invasi militer terhadap Suriah juga tak mendapat autorisasi dari kongres maupun masyarakat sehingga tak ada legitimasi bagi Amerika Serikat untuk menggunakan hard power sebagai strategi diplomasinya. Strategi hard power justru dapat merugikan pemerintah Amerika Serikat dengan adanya indikasi hilangnya kepercayaan 
Jurnal Administrasi Negara

ISSN : 2598-4039 (Online)

ISSN : 2302-2231 (Print)
Syuryansyah, Andrialius Feraera

Universitas Serang Raya publik Amerika Serikat apabila pemerintah tetap mengedepankan strategi hard power.

Sedangkan strategi diplomasi soft power melalui jalur perundingan dan negosiasi dianggap sebagai strategi yang lebih menguntungkan. Keuntungan soft power berupa : Amerika Serikat dapat menghemat cost dan anggaran militer yang beresiko membengkak apabila perang terjadi serta dapat menghindari jatuhya korban jiwa dari pihak Amerika Serikat. Selain itu, Amerika Serikat juga dapat memperoleh dukungan dari dalam negeri termasuk masyarakat AS maupun kongres, bahkan dunia internasional karena keputusan Amerika Serikat yang lebih mengedepankan peacefull means daripada pendekatan koersif. Secara singkat, perbandingan strategi hard power dan soft power seperti pada tabel di bawah ini.

Tabel 1

Perbandingan Hard Power Dan Soft Power

\begin{tabular}{cllll}
\hline Strategi Diplomasi & $\begin{array}{l}\text { Kalkulasi } \\
\text { Untung Rugi } \\
\text { Ekonomi }\end{array}$ & \multicolumn{2}{c}{ Kalkulasi Untung Rugi Politik } \\
\hline Hard Power & High Cost & 1. $\begin{array}{l}\text { Tidak adanya dukungan dari } \\
\text { internal AS }\end{array}$ & \\
& 2. & Kecaman dunia internasional \\
& 3. & Kaburnya posisi lawan di Suriah \\
\hline Soft Power & Low Cost & 2. & Besarnya dukungan internal AS \\
& & & Memperoleh simpati dunia \\
& & &
\end{tabular}

\section{METODE PENELITIAN}

Jangkauan penelitian dibatasi pada kisaran tahun 2013 hingga tahun 2014. Tahun 2013 dipilih sebagai awal penelitian karena tahun tersebut merupakan momentum penting keterlibatan Amerika Serikat dalam konflik internal Suriah yang ditandai dengan dilakukannya serangkaian upaya diplomasi dalam bentuk hard power. Sedangkan tahun 2014 dipilih sebagai batas akhir penelitian karena pada tahun tersebut terjadi titik balik perubahan strategi diplomasi yang digunakan oleh Amerika Serikat. Kemudian, konflik internal yang terjadi di Suriah dipilih sebagai fokus penelitian karena strategi yang 
Jurnal Administrasi Negara

ISSN : 2598-4039 (Online)

ISSN : 2302-2231 (Print)
Syuryansyah, Andrialius Feraera

Universitas Serang Raya diterapkan Amerika Serikat dalam konflik di wilayah Suriah ini sangat berbeda dengan strategi yang diterapkan AS sebelumnya pada negara - negara konflik lainnya seperti yang dilakukan terhadap Irak maupun Afghanistan, dimana Amerika Serikat cenderung menggunakan hard power tanpa melakukan perubahan strategi ke arah soft power.

Metode pengumpulan data yang digunakan adalah metode kualitatif yang didasarkan pada penelitian kepustakaan (Library Research) dimana data - data yang diperoleh merupakan data sekunder yang diambil dari berbagai sumber yakni buku - buku ilmiah atau hasil penelitian, dokumen dokumen, jurnal, majalah, surat kabar, internet dan media lainnya yang relevan dengan objek penelitian.

Metode analisis data yang digunakan adalah teknik analisis deduktif dimana digunakan beberapa teori terlebih dahulu lalu kemudian data dan fakta dikumpulkan sebagai bahan untuk menganalisis relasi dan keterkaitan antara teori dengan data dan fakta terkait secara sistematis.

\section{HASIL DAN PEMBAHASAN}

Dengan menggunakan teori model aktor rasional yang di tela'ah dengan menggunakan data - data yang telah diperoleh, Amerika Serikat mengubah strategi diplomasinya dari hard power menjadi soft power dalam konflik internal Suriah karena adanya kalkulasi untung rugi secara ekonomi dan secara politik.

\section{Kalkulasi Untung Rugi Secara Ekonomi}

Penghematan Biaya Dan Anggaran Militer Amerika Serikat

Perang selalu membutuhkan biaya yang besar dan beresiko membebani anggaran militer dan stabilitas ekonomi suatu negara. Pada Perang Afghanistan maupun Irak, Harvard University's Kennedy School of Government mencatat bahwa Amerika Serikat telah mengeluarkan biaya hingga USD 6 Triliun (Global Research, 2015). Angka tersebut termasuk biaya peralatan militer, logistik, biaya personel pasukan serta biaya perawatan jangka panjang dan kompensasi disabilitas terhadap veteran perang beserta keluarga (Time News, 2014). Dalam Operasi Pembebasan Irak, Deparment of Defense Amerika Serikat mengeluarkan biaya hingga USD 7 - 10 juta perharinya. Sedangkan dalam Perang Afghanistan, Amerika Serikat tercatat telah mengeluarkan biaya hingga ratusan juta dolar perharinya. New York Times juga mencatat bahwa sejak peristiwa pengeboman gedung WTC pada 9/11, Amerika Serikat telah 
Jurnal Administrasi Negara

ISSN : 2598-4039 (Online)

ISSN : 2302-2231 (Print)

\author{
Syuryansyah, Andrialius Feraera \\ Universitas Serang Raya
}

mengeluarkan USD 3,3 Triliun untuk mengatasi kejatuhan ekonomi akibat serangan teroris dan juga untuk membiayai keamanan dalam negeri Amerika Serikat.

Dalam kasus Suriah ini, Amerika Serikat bahkan beresiko mengeluarkan biaya yang jauh lebih besar dari jumlah di atas apabila strategi hard power dijalankan. Tanpa terlibat perang secara langsung pun, Amerika Serikat telah mengeluarkan biaya yang sangat besar di Suriah (Breitbart, 2013). Pemerintah Amerika Serikat tercatat telah mengajukan permintaan anggaran negara untuk tahun 2015 sebesar USD 46,2 Milyar untuk membiayai kebutuhan Departemen Luar Negeri dan US Agency for International Development, dimana USD 1,5 Milyar diantaranya digunakan untuk membantu pengungsi Suriah yang menjadi korban peperangan (Journalist Resource, 2013). Sejak tahun 2011, Amerika Serikat telah memberikan bantuan kemanusiaan kepada korban perang di Suriah hingga mencapai USD 1,4 Milyar. Pada tahun 2014, Amerika Serikat mengeluarkan bantuan kemanusiaan internasional sebesar USD 380 Milyar kepada pengungsi Suriah. Bantuan tersebut mencakup kebutuhan makanan dan minuman, obat - obatan serta shelter bagi korban perang.
Besarnya biaya kemanusiaan tersebut tak sebanding dengan besarnya biaya perang yang beresiko di tanggung Amerika Serikat di Suriah. Apabila pada Perang Irak dan Afghanistan Amerika Serikat menghabiskan biaya sekitar USD 6 Triliun, maka keterlibatan Amerika Serikat dalam Perang Sipil Suriah akan beresiko menghabiskan biaya sekitar USD 30 hingga 40 Milyar pertahunnya yang mencakup biaya persenjataan, manpower dan bantuan bagi koalisi. Biaya perang tersebut masih beresiko membengkak mengingat musuh terbesar Amerika Serikat yang cenderung mencengkeram Suriah kali ini kian berkembang salah satunya yakni ISIL, kelompok militan ekstrimis islam dengan tingkat kompleksitas tinggi untuk dihadapi. Perang melawan militan ekstrimis tersebut beresiko memakan biaya hingga USD 416 Juta setiap bulannya (The Atlantic, 2014). Angka tersebut dapat mencapai hingga USD 30 Milyar setiap tahun apabila Amerika Serikat menggunakan serangan udara melalui 47 misil tomahawk dan 200 pesawat jet tempur milik Amerika Serikat dan koalisi. Para analis militer juga menyatakan bahwa Overseas Contingency War Operation yang dijalankan Amerika Serikat di timur tengah telah mencapai angka hingga USD 65,8 Milyar dan menyebabkan anggaran fiskal Amerika Serikat pada 
Jurnal Administrasi Negara

ISSN : 2598-4039 (Online)

ISSN : 2302-2231 (Print)
Syuryansyah, Andrialius Feraera

Universitas Serang Raya tahun 2015 meningkat mencapai USD 496 Milyar (National Priorities, 2014). Biaya tersebut bahkan jauh melampaui besarnya biaya perang selama 13 tahun di Afghanistan maupun Irak. Tentunya dalam hal ini, Amerika Serikat akan sangat membutuhkan bantuan finansial maupun militer dari NATO maupun aliansi nya di timur tengah.

Sejumlah analisis dari Center for Strategic and Budgetary Assessments memprediksi bahwa serangan udara intensitas rendah oleh Amerika Serikat terhadap Suriah dapat menghabiskan biaya sekitar USD 2.4 - 3.8 Milyar pertahunnya. Serangan udara intensitas tinggi dapat memakan biaya hingga USD 4.2 - 6.8 Milyar pertahunnya, sedangkan serangan total di Suriah dengan menerjunkan pasukan darat sebesar 25.000 personel dapat menghabiskan biaya hingga USD 30 Milyar (The Fiscal Times, 2014). Angka tersebut belum termasuk biaya operasi khusus dan biaya untuk mempersenjatai serta melatih kubu oposisi sekular Suriah yang sejak 2012 silam telah dilatih oleh Amerika Serikat di sekitar perbatasan Jordan di bawah pengawasan CIA. Biaya pelatihan dan pemberian bantuan kepada pasukan oposisi sekular seperti kurdi maupun Free Syrian Army bahkan dapat memakan biaya hingga USD 3 Milyar (Huffington Post, 2013). Selama perang berlangsung, Amerika Serikat juga harus meningkatkan anggaran bagi perlindungan keamanan dalam negerinya yang mencakup biaya pengamanan perbatasan, pengamanan sumber logistik bagi negaranya, homeland security maupun peningkatan cyber security dan perlindungan terhadap kepentingan nasional Amerika Serikat lainnya yang tersebar di timur tengah. Tercatat pada tahun 2014 Amerika Serikat menghabiskan anggaran hingga USD 70 Milyar bagi operasi pengamanan dalam negerinya (Foreign Policy, 2014).

Menghindari Besarnya Biaya Kompensasi Veteran Perang Akibat Jatuhnya Korban Jiwa Dari Pihak Amerika Serikat

Penggunaan strategi hard power beresiko menyebabkan tingginya korban jiwa yang berjatuhan dari pihak Amerika Serikat yang secara langsung berakibat pada membengkaknya biaya yang akan ditanggung oleh Amerika Serikat. Setiap personil Amerika Serikat yang menjadi korban dalam perang akan memperoleh biaya perawatan jangka panjang dan kompensasi pasca perang bagi veteran (Time News, 2014).

Dalam Operasi Pembebasan Irak misalnya, Deparment of Defense Amerika Serikat mencatat bahwa 4.425 pasukan Amerika Serikat meninggal dunia, 
Jurnal Administrasi Negara

ISSN : 2598-4039 (Online)

ISSN : 2302-2231 (Print)

\author{
Syuryansyah, Andrialius Feraera \\ Universitas Serang Raya
}

32.223 lainnya terluka, 725 pasukan mengalami amputasi, dan 360.000 veteran perang mengalami brain traumatic syndrome (Global Security, 2014). Sedangkan pada Perang Afghanistan, sebanyak 2.326 pasukan Amerika Serikat meninggal dunia dan 20.083 lainnya terluka (iCasualties, 2015). Bahkan dalam keterlibatan Amerika Serikat pada Perang Vietnam beberapa tahun silam, tercatat korban jiwa dari pihak Amerika Serikat yang meninggal dunia mencapai angka hingga 58.178 jiwa (Military Factory, 2014).

Besarnya angka korban jiwa yang berjatuhan tersebut menyebabkan Pemerintah Amerika Serikat mengeluarkan dana kompensasi sebesar lebih dari USD 40 miliar atau setara dengan Rp 388,3 triliun, setiap tahunnya sebagai kompensasi untuk para veteran dan keluarga yang ditinggalkan akibat Perang. Pemerintah Amerika Serikat bahkan masih akan terus membayar biaya bulanan keluarga veteran Perang Sipil hingga 148 tahun setelah konflik berakhir. Meskipun Perang Dunia I telah berakhir 94 tahun yang lalu, Amerika Serikat terus mengeluarkan biaya hingga USD 20 juta per tahunnya. Biaya kompensasi Perang Dunia II yang dikeluarkan Amerika Serikat juga telah mencapai USD 5 miliar per tahun. Untuk Perang Sipil dan Perang Spanyol
- Amerika, biaya total yang dikeluarkan pemerintah bahkan mencapai USD 50.000 per tahun (Kompas, 2013).

Setiap tahunnya, biaya kompensasi perang terus mengalami peningkatan. Pada kompensasi veteran yang terlibat Perang Vietnam misalnya, biaya kompensasi terus meningkat hingga di atas USD 22 miliar walaupun Amerika Serikat telah mengeluarkan biaya selama 40 tahun pasca perang tersebut berakhir (Global Security, 2014). Hingga saat ini, lebih dari setengah dari 1.56 juta veteran perang Amerika Serikat yang menjadi korban dalam peperangan telah menerima perawatan medis di bawah penanganan United States of Veteran Affairs.

Selama ini, Pemerintah Amerika Serikat membayar kompensasi perang sepenuhnya dari hutang dan pemotongan pajak yang dibebankan kepada masyarakat. Selama tahun 2001 hingga 2012, tercatat bahwa hutang nasional Amerika Serikat telah bertambah sebesar USD 2 triliun yang merupakan 20\% dari total hutang nasional. Sedangkan biaya Perang Irak yang dibebankan kepada pembayar pajak Amerika Serikat telah mencapai USD 1,7 triliun (Kompas, 2013). Angka tersebut belum termasuk biaya perawatan untuk masa depan veteran dan bunga pinjaman biaya perang.Beban bunga pinjaman untuk 
Jurnal Administrasi Negara

ISSN : 2598-4039 (Online)

ISSN : 2302-2231 (Print)
Syuryansyah, Andrialius Feraera

Universitas Serang Raya biaya Perang Irak diperkirakan akan mencapai USD 4 triliun pada tahun 2053 mendatang.

Selain besarnya biaya yang akan diperuntukkan untuk kompensasi veteran perang, Pemerintah Amerika Serikat juga berpotensi untuk menanggung besarnya biaya rekonstruksi pasca konflik apabila hard power digunakan oleh Amerika Serikat di Suriah, Pasca Perang Irak yang melibatkan Amerika Serikat, kongres tercatat telah mengalokasikan dana hingga USD 53 miliar guna mendanai keperluan rekonstruksi di Irak. Departemen Pertahanan Amerika Serikat juga telah mengucurkan dana sebesar USD 9,1 miliar untuk biaya rekonstruksi tersebut sejak tahun 2004 hingga 2007 (Global Security, 2014). Angka ini berpotensi akan membengkak dalam kasus di Suriah.

Terlepas dari hal tersebut, sebelum terlibat dalam peperangan secara langsung, Amerika Serikat sebelumnya juga telah melatih sekitar 5000 militan oposisi sekular untuk menjadi pejuang di Suriah dan bertarung melawan kubu ekstrimis islam Suriah (Washington Post, 2013). Namun dalam perkembangannya, pasukan oposisi yang di latih Amerika Serikat secara rahasia tersebut banyak mengalami kekalahan di medan pertempuran. Dari sekian ribu jumlah pasukan yang dilatih, hanya sekian ratus diantaranya yang berhasil kembali ke markas pelatihan dengan selamat pasca bertempur. Pelatihan yang diberikan Amerika Serikat terhadap kubu oposisi tersebut memang cukup untuk melakukan counter attack terhadap lawan yang ditargetkan, namun hal itu tidak menjaminkan kemenangan bagi pasukan tersebut. Kecilnya angka survival pasukan tersebut juga menjadi salah satu pertimbangan bagi Amerika Serikat untuk mengubah strategi diplomasinya ke arah diplomasi soft power. Korban jiwa dalam konflik berkepanjangan di Suriah telah mencapai angka keseluruhan hingga 70.000 jiwa berdasarkan data dari Komisi Tinggi Hak Asasi Manusia PBB (CNN, 2014). Angka tersebut lebih tinggi dari total keseluruhan korban jiwa dari pihak Amerika Serikat yang meninggal dunia dalam Perang Vietnam, Perang yang memakan korban jiwa terbanyak dari pihak Amerika Serikat. Keterlibatan Amerika Serikat secara langsung dalam konflik Suriah tidak menutup kemungkinan terulangnya peristiwa serupa bagi Amerika Serikat seperti Perang Vietnam, mengingat aktor yang terlibat dalam konflik ini jauh lebih kompleks dan lebih banyak dibandingkan dengan perang - perang 
Jurnal Administrasi Negara

ISSN : 2598-4039 (Online)

ISSN : 2302-2231 (Print)
Syuryansyah, Andrialius Feraera

Universitas Serang Raya sebelumnya yang pernah melibatkan Amerika Serikat.

\section{Kalkulasi Untung Rugi Secara Politik Memperbesar Dukungan Dari Internal Amerika Serikat}

Proposal Presiden Obama untuk menggunakan hard power dalam konflik internal Suriah tak mendapat sambutan positif dari masyarakat maupun kongres. Sebelum draft proposal Presiden Obama untuk menggunakan langkah militer di Suriah di bahas di House of Representative, sebagai partai oposisi pemerintah, para anggota Partai Republik secara tegas menyatakan penolakannya terhadap kebijakan Presiden Obama tersebut mengingat Perang Sipil Suriah dianggap tidak menimbulkan ancaman langsung bagi Amerika Serikat. Voting House of Representative kemudian menghasilkan keputusan bahwa mayoritas suara House of Representative yang mencapai 155 menolak untuk mendukung kebijakan militer Presiden Obama di Suriah, 120 diantaranya merupakan anggota Partai Republik dan 36 suara berasal dari partai Demokrat. Hanya 32 suara yang menyatakan dukungannya sedangkan 93 suara lainnya menyatakan abstain (Washington Post, 2013).

Mayoritas publik Amerika Serikat juga menentang kuat keputusan Presiden Obama untuk menjalankan kebijakan militer di Suriah. Sejumlah online polling diadakan dan diikuti oleh sekitar 1.195 penduduk Amerika Serikat sejak 30 Agustus hingga 3 September 2013. Polling tersebut memiliki kredibilitas hingga 95\% (CNN, 2013). International polling yang diadakan juga menghasilkan bahwa 70\% koresponden tidak meyakini bahwa serangan militer akan membuat Amerika Serikat mencapai tujuannya di Suriah, koresponden juga menyatakan bahwa Amerika Serikat tidak memiliki kepentingan langsung di Suriah yang harus dilindungi melalui serangkaian serangan militer. Berdasarkan polling tersebut, walaupun kongres menyetujui kebijakan Presiden Obama, 55\% penduduk Amerika Serikat tetap menyatakan penolakannya terhadap segala bentuk serangan militer terhadap Suriah. Polling juga menghasilkan bahwa 59\% penduduk bahkan tetap menentang kebijakan kongres yang memberikan autorisasi terhadap penggunaan serangan militer terbatas selama 90 hari di Suriah.

Publik menyatakan bahwa intervensi militer tak akan menghasilkan perubahan apapun ke arah yang lebih baik di Suriah. Pasca terjadinya serangkaian revolusi di timur tengah, publik Amerika meyakini bahwa Pemerintah Amerika Serikat mampu meraih kesuksesan hanya 
Jurnal Administrasi Negara

ISSN : 2598-4039 (Online)

ISSN : 2302-2231 (Print)

\section{Syuryansyah, Andrialius Feraera \\ Universitas Serang Raya}

dengan menggunakan strategi yang terbatas di timur tengah, sehingga segala bentuk tindakan militer tidak diperlukan. Minimnya dukungan publik dan kongres Amerika Serikat kemudian menjadi salah satu alasan terbesar Presiden Barrack Obama untuk mengubah strategi diplomasi Amerika Serikat dari hard power menjadi soft power dalam konflik internal Suriah. Penggunaan soft power dianggap mampu untuk memperbesar dukungan publik terhadap kebijakan yang akan dijalankan pemerintah Amerika Serikat di Suriah.

\section{Memperoleh Simpati dan Dukungan Internasional}

Dari 5 negara anggota tetap Dewan Keamanan PBB, yang menyatakan dukungan penuh kepada Amerika Serikat hanya Perancis. Inggris menolak untuk ikut serta bersama Amerika Serikat dalam melakukan serangan militer terhadap Suriah pasca publik dan Parlemen Inggris menyatakan penolakannya terhadap proposal kebijakan militer yang diajukan oleh Perdana Menteri Inggris, David Cameron (Telegraph, 2013). Berbagai bentuk resolusi oleh dewan keamanan PBB yang ditujukan untuk menyudutkan Suriah dalam bentuk sanksi - sanksi maupun upaya intervensi guna menanggapi konflik berkepanjangan di Suriah terus menemui jalan buntu. China dan Rusia selaku anggota tetap DK PBB selalu memveto setiap draft resolusi yang dicanangkan (ICR, 2013). Gagalnya pembentukan resolusi untuk melakukan sejumlah intervensi terhadap Suriah menyebabkan Amerika Serikat kekurangan dukungan internasional untuk menjalankan kebijakannya. Publik dan parlemen Jerman juga menyatakan penolakannya atas kebijakan Pemerintah untuk mensupport Amerika Serikat dalam tindakan militernya terhadap Suriah (Der Spiegel, 2013). Uni Eropa juga menolak untuk memberikan dukungan karna tak adanya mandat dari PBB yang disebabkan gagalnya pembentukan resolusi oleh Dewan Keamanan PBB. Tidak adanya mandat dari PBB yang membenarkan segala tindakan intervensi militer membuat negara negara cenderung memilih untuk menolak menggunakan kekuatan militer terhadap Suriah (Independent News, 2013). Minimnya dukungan internasional terutama dukungan PBB akan menyebabkan setiap tindakan militer Amerika Serikat di Suriah digolongkan sebagai aksi unilateral yang mengarah pada tindakan intervensi dan aneksasi terhadap kedaulatan Suriah. 
Jurnal Administrasi Negara

ISSN : 2598-4039 (Online)

ISSN : 2302-2231 (Print)
Syuryansyah, Andrialius Feraera

Universitas Serang Raya
Dalam perkembangannya, dukungan militer terhadap setiap kebijakan militer Amerika Serikat di Suriah hanya diberikan oleh negara teluk dan sejumlah negara timur tengah terutama negara yang berbatasan langsung dengan Suriah seperti Turki maupun Jordan. Namun kemudian, hubungan Amerika Serikat dengan Turki juga sedang berada dalam posisi yang rapuh. Pada awalnya, dukungan militer dalam bentuk pelatihan dan bantuan militer serta finansial terhadap kubu oposisi sekuler Suriah seperti Free Syrian Army merupakan konsen bersama antara Amerika Serikat dan Turki. Turki pun telah memberikan akses bagi Amerika Serikat untuk mengadakan pelatihan terhadap oposisi tersebut di sekitar perbatasan Turki. Turki bahkan mengizinkan Free Syrian Army untuk mendirikan markas eksternalnya di Istanbul (BBC, 2013).

Namun kerjasama antara kedua negara menjadi kontras apabila dikaitkan dengan kelompok oposisi militan Kurdi. Turki memiliki hubungan yang buruk dengan kelompok Kurdi baik kurdi Suriah yakni Democratic Unity Party (PYD) dan Tentara bersenjata People's Protection Units (YPG), Kurdi Irak (Kurdi regional Government), terutama dengan kelompok kurdi di Turki--Partiya Karkeren Kurdistan (Kurdistan Workers
Party atau PKK). Hubungan buruk Turki dengan Kurdi memanas semenjak Turki menetapkan PKK sebagai organisasi teroris setelah 40 tahun kelompok tersebut terlibat konflik dengan Pemerintah Turki di perbatasan Kobani sejak tahun 1984. Perkembangan kelompok kurdi Irak dan Suriah yang semakin memperluas pengaruhnya di wilayah menjadi konsen terbesar Turki karena perluasan pengaruh tersebut berpotensi memberikan kesempatan pada kelompok kurdi regional terutama Kurdi Turki untuk membentuk pemerintahan kurdi yang merdeka dan independen dengan wilayah yang lebih luas dan mencakup sebagian wilayah Turki. Bagi Turki, Kurdi merupakan ancaman terbesar bagi kedaulatan dan keamanan Turki, bahkan melebihi ancaman dari ISIL.

Namun di sisi lain, Kelompok Kurdi yakni PKK dan YPG bekerjasama untuk melawan serangan ISIL (The Guardian, 2015). Bahkan kelompok kurdi sepenuhnya di back up oleh Amerika Serikat. Semenjak invasi militernya ke Irak, Kurdi merupakan salah satu kelompok loyalis bagi Amerika Serikat. Dalam konflik Suriah kali ini pun, kelompok minoritas kurdi Suriah dan Irak merupakan kubu penting yang digunakan Amerika Serikat untuk melakukan counter attack 
Jurnal Administrasi Negara

ISSN : 2598-4039 (Online)

ISSN : 2302-2231 (Print)

\author{
Syuryansyah, Andrialius Feraera \\ Universitas Serang Raya
}

dan menahan laju perluasan pengaruh ISIL (Council on foreign relations, 2014).

Kedekatan Amerika Serikat dengan Kurdi menyebabkan timbulnya situasi yang rumit antara Amerika Serikat dengan Turki. Bahkan unutk menanggapi kedekatan Amerika Serikat dan kurdi, Turki bahkan sempat menolak untuk memberikan izin bagi Amerika Serikat untuk menggunakan pangkalan udaranya untuk menyerang Suriah. Media Turki bahkan menginformasikan bahwa Intelijen Nasional Turki secara rahasia telah mempersenjatai kelompok jihadis yang berafiliasi dengan $A l$ Qaeda. Kondisi tersebut secara nyata menyebabkan Amerika Serikat berada dalam kondisi dilematis. Turki menjadi kawan bagi Amerika Serikat ketika berhadapan dengan ISIL, namun sekaligus menjadi lawan ketika kedua negara dikaitkan dengan Kurdi (Huffington Post, 2014).

Di sisi lain, Amerika Serikat sangat membutuhkan Kurdi untuk melawan baik kubu Pemerintahan Bashar Al Assad dan kubu oposisi islam radikal. Perkembangan kelompok jihad islam radikal dalam konflik Suriah merupakan konsen utama bagi Amerika Serikat (Washington Post, 2013). CIA mencatat bahwa dari sekitar 100.000 pejuang oposisi di Suriah, lebih dari 20.000 diantaranya merupakan militan ekstrimis yang muncul sebagai salah satu ancaman besar bagi Amerika Serikat (Washington Post, 2013). Faksi politik dalam perang sipil Suriah telah berkembang menjadi berbagai kubu besar dalam jumlah yang massiv mencapai angka hingga lebih dari 50 kelompok militan.

Besarnya kepentingan politis Amerika Serikat untuk mempertahankan Kurdi tak berhenti sampai disitu. Amerika Serikat membutuhkan Kurdi karena pasukan oposisi sekuler yang dilatih secara rahasia oleh Amerika Serikat sedang menghadapi kondisi yang cukup sulit. Angka rekruitmen calon pejuang yang akan dilatih oleh CIA mengalami penurunan. Pada salah satu kamp terbesar di Jordan yang melatih hingga 100.000 pejuang oposisi sekuler, tercatat bahwa setiap harinya, ratusan pejuang menuju Suriah untuk bertempur dan hanya jumlah kecil diantara mereka yang kembali dengan selamat (News Week, 2014). Posisi ini merupakan salah satu kondisi sulit yang dialami oleh Amerika Serikat sebagai pendonor terbesar bagi oposisi sekuler tersebut.

Dilematisnya hubungan Amerika Serikat dengan Turki yang disebabkan oleh adanya konsen besar yang diberikan Amerika Serikat terhadap Kurdi pun menjadi hal yang dapat membawa akibat buruk bagi Amerika Serikat. Karena sejatinya, keberadaan 
Jurnal Administrasi Negara

ISSN : 2598-4039 (Online)

ISSN : 2302-2231 (Print)

\author{
Syuryansyah, Andrialius Feraera \\ Universitas Serang Raya
}

Turki sebagai aliansi Amerika Serikat di Timur Tengah merupakan hal penting yang harus dipertahankan. Namun di sisi lain, keberadaan Kurdi juga sangat penting karena menjadi ujung tombak bagi Amerika Serikat untuk melakukan counter attack dalam melawan kebangkitan puluhan kelompok radikal islam di Suriah yang berpotensi membahayakan kepentingan nasional Amerika Serikat. Kepentingan politis untuk mempertahankan hubungannya dengan Kurdi sekaligus tetap mendapat dukungan dari Turki kemudian muncul sebagai salah satu faktor penyebab Amerika Serikat mengubah strategi diplomasinya dari hard power menjadi soft power.

Adanya hubungan dilematis dalam konflik Suriah tak hanya dialami Amerika Serikat dengan Turki dan Kurdi semata. Hal yang serupa terjadi pada hubungan Amerika Serikat dan Irak. Sejumlah Operasi Militer Gabungan antara militer Irak dan Amerika Serikat memang telah dibentuk untuk mengamankan areal perbatasan terutama di sebelah barat Provinsi Anbar dari serangan jihadist ekstrimis islam dari Suriah. Namun sejumlah sumber menyebutkan Irak telah memberikan akses bagi pesawat Iran yang mengangkut senjata dan suplai bagi kubu pemerintah Suriah untuk transit di wilayah Irak. Hal ini menyebabkan posisi Amerika Serikat berada dalam kondisi yang dilematis. Irak sekaligus berperan sebagai lawan dan kawan bagi Amerika Serikat dalam konflik internal Suriah.

Terlepas dari itu, segala upaya militer yang akan dilakukan Amerika Serikat di Suriah juga berpotensi membawa kembali image buruk Amerika Serikat sebagai negara aggressor dimana tentunya hal tersebut kontras dengan prinsip Amerika Serikat sebagai negara yang menjunjung tinggi demokrasi. Sejumlah perang yang dilakukan oleh Amerika Serikat di beberapa negara seperti Irak dan Afghanistan menanamkan citra yang negatif untuk Amerika Serikat. Apabila tindakan intervensi militer serupa dilakukan kembali di Suriah, maka upaya rekonstruksi image yang telah dijalankan sejak masa pemerintahan Presiden Obama di Amerika Serikat akan menuai hasil yang sia - sia. Segala bentuk intervensi militer beresiko memunculkan kembali image buruk Amerika Serikat di mata internasional.

\section{PENUTUP SIMPULAN}

Amerika Serikat mengubah strategi diplomasinya dari hard power menjadi soft power disebabkan oleh dua pertimbangan utama, yakni kalkulasi 
Jurnal Administrasi Negara

ISSN : 2598-4039 (Online)

ISSN : 2302-2231 (Print)

\author{
Syuryansyah, Andrialius Feraera \\ Universitas Serang Raya
}

untung rugi secara ekonomi dan kalkulasi untung rugi dari segi politik. Dari segi ekonomi, strategi soft power jauh lebih menguntungkan daripada menggunakan strategi diplomasi hard power. Melalui soft power, Amerika Serikat dapat menghemat biaya dengan tidak harus mengalokasikan anggaran militernya untuk membiayai peperangan yang notabenenya selalu membutuhkan biaya yang besar. Terlebih perang sipil di Suriah melibatkan multiaktor yang cukup kompleks dan sulit diprediksi kapan akan berakhirnya. Selain itu, dengan soft power, besarnya biaya kompensasi bagi veteran perang yang akan dikeluarkan akibat adanya korban jiwa dari pihak Amerika Serikat juga dapat dihindari.

Di sisi lain, berdasarkan kalkulasi untung rugi secara politik, strategi soft power jauh lebih menguntungkan bagi Amerika Serikat dalam tiga hal utama. Yang pertama yakni untuk memperbesar dukungan dari internal Amerika Serikat, karena sejak memutuskan untuk menggunakan hard power, dukungan publik terhadap pemerintah Amerika Serikat terhitung sangat kecil, dibuktikan melalui pengadaan sejumlah polling dan public hearing. Minimnya dukungan publik tersebut kemudian menyebabkan kongres Amerika Serikat menolak untuk memberikan autorisasi dan persetujuan kepada Presiden untuk melaksanakan invasi militer terhadap Suriah.

Kedua, Amerika Serikat mengubah strategi diplomasinya juga untuk memperoleh simpati dan dukungan dari internasional. Dalam kebijakannya untuk menggunakan strategi hard power, Amerika Serikat tidak memperoleh dukungan dari negara - negara aliansi Amerika Serikat seperti Inggris, Kanada, Jerman maupun Australia. Dari 5 negara anggota tetap Dewan Keamanan PBB, yang menyatakan dukungan penuh kepada Amerika Serikat hanya Perancis (Telegraph, 2013). Selain itu, semakin bertambahnya faksi politik yang terlibat dalam konflik internal Suriah menyebabkan semakin kaburnya posisi lawan dan kawan bagi Amerika Serikat. Keterlibatan aktor internasional dan berbagai pejuang eksternal juga turut memperparah keadaan konflik hingga menyebabkan konflik berubah ke arah Proxy War. Konflik Suriah juga telah menimbulkan kondisi dilematis bagi Amerika Serikat dan beberapa aliansinya di timur tengah baik negara maupun kelompok oposisi yang di back up oleh Amerika Serikat. Adanya kalkulasi untung rugi dari segi ekonomi maupun politik tersebut kemudian menjadi penyebab dibalik adanya 
Jurnal Administrasi Negara

ISSN : 2598-4039 (Online)

ISSN : 2302-2231 (Print)

\section{Syuryansyah, Andrialius Feraera \\ Universitas Serang Raya}

perubahan strategi yang dilakukan oleh Amerika Serikat.

\section{REFERENSI}

ABC News. (2013). Retrieved september 20, 2015, from Politics - Syrian Civil War:

http://abcnews.go.com/Politics/syriancivil- war/story?id=20112311

ABC News. (2013). Retrieved october 25, 2015, from News: http://www.abc.net.au/news/2013-08$\underline{\text { 28/fitzpatrick-syria/4918406 }}$

ABC News. (2014). Retrieved september 20, 2015, from International, key players syrian civil war: http://abcnews.go.com/ International/key-players-syrian-civilwar/story? id $=20108422$

Ar Rahmah . (2013). Retrieved october 25, 2015, from News: http://www. arrahmah.com/ news/2013/04/28/milisisyiah-hibzullah-kerahkan-sepertigapasukannya-untuk-selamatkan-rezimsuriah.html

BBC. (2013). Retrieved March 20, 2015, from Dunia: http://www.bbc.co.uk/ indonesia/dunia/2013

BBC. (2013). Retrieved october 25, 2015, from News: http://www.bbc.com/ news/world-middle-east-33690060
Breitbart. (2013). Retrieved october 25, 2015, from National Security: http://www.breitbart.com/nationalsecurity/2013/09/08/us-spent-1-010-354195-in-syrian-humanitarian-aid-20122013/

Britannica. (2014). Retrieved from United States:

http://britannica.com/EBchecked/United -States

Business Dictionary. (2010). Retrieved december 22, 2015, from Definition of tactics:

http://businessdictionary.com/definition /tactics.html

CBC. (2014). Retrieved october 25, 2015, from News: http://www.cbc.ca/news2/ interactives/isis-allies-enemies/ interactive.html 1 .

CNN. (2013). Retrieved october 25, 2015, from Politics: http://edition.cnn.com/2013/09/09/politic s/syria-poll-main/

CNN. (2013). Retrieved October 25, 2015, from Public against Syria strike resolution: http://www.cnn.com

CNN. (2013). Retrieved October 25, 2015, from Obama hits new low on foreign 
Jurnal Administrasi Negara

ISSN : 2598-4039 (Online)

ISSN : 2302-2231 (Print)
Syuryansyah, Andrialius Feraera

Universitas Serang Raya policy in $\mathrm{CNN}$ polling: http://www.cnn.com

CNN. (2014). Retrieved october 25, 2015, from Syria death toll: http://edition.cnn.com/2014/02/12/world /meast/syria-death-toll/

Consilium Europe. (2013). Retrieved september 20, 2015, from Goals of Diplomacy: http://www.consilium. europa.eu/uedocs/cmsUpload/Cooperar ticleGoalsodiplomacyweb.pdf

Council on foreign relations. (2014). Retrieved october 25, 2015, from Kurds: http://www.cfr.org/middle-east-andnorth-africa/time-kurds/p36547?cid=otrmarketing-use-Kurds_InfoGuide\#!/

Der Spiegel. (2013). Retrieved october 25, 2015, from International: http://www.spiegel.de/international/wo rld/german-pundits-weigh-pros-andcons-of-syria-intervention-a-918849.html

Detik News. (2013). Retrieved september 20, 2015, from International: http://news.detik.com/internasional/240 8277/batal-serang-suriah-kapal-perangas-ditarik-pulang-dari-teluk-persia

Deutsche Welle. (2014). Retrieved september 20, 2015, from Actors Interest and a Proxy Tug of War in Syria: http://www.dw.com/en/actors-interestsand-a-proxy-tug-of-war-in-syria/a17103525

Foreign Affairs. (2011). Retrieved september 20, 2015, from Soft Power Means Success World Politics: https://www.foreignaffairs.com/softpower-means-success-world-politics

Foreign Policy . (2013). Retrieved october 25, 2015, from An Open Letter to My Congressman About Syria: http://www.foreignpolicy.com

Foreign Policy. (2006, february 23). Retrieved september 20, 2015, from Think Again Soft Power: http://foreignpolicy.com/2006/02/23/thin k-again-soft-power/

Foreign Policy. (2014). Retrieved october 25, 2015, from How The New 60 Million spent:

http://foreignpolicy.com/2014/03/13/ho w-the-new-60-million-of-syria-aid-isbeing-spent/

Global Research. (2015). Retrieved October 8, 2015, from US Wars in Afghanistan and Iraq Cost: http://www.globalresearch.ca/us-warsin-afghanistan-iraq-to-cost-6trillion/5350789 
Jurnal Administrasi Negara

ISSN : 2598-4039 (Online)

ISSN : 2302-2231 (Print)

\section{Syuryansyah, Andrialius Feraera \\ Universitas Serang Raya}

Global Security. (2014). Retrieved October 8, 2015, from US Casualties in Iraq: U.S. Casualties in Iraq. http//www.GlobalSecurity.org diakses pada 8 Oktober 2015

Graham T.Allison. (1963). Conceptual Models and the Cuban Missile Crisis. The American Political Science Review vol.63.

Huffington Post. (2013). Retrieved october 25, 2015, from US Aid to syrian rebels: $\quad$ http://www.huffingtonpost. com/2013/02/28/us-aid-to-syrian-rebels_ n_2780864.html

Huffington Post. (2014). Retrieved october 25, 2015, from The Enemy of my enemy:

http://www.huffingtonpost.com/josephv-micallef/the-enemy-of-my-enemyisl_b_6542108.html

Huffington Post. (2014). Retrieved october 25, 2015, from http://www.huffingtonpost.com/2014/10 /16/syrian-kurds-isis_n_5999610.html iCasualties. (2015). Retrieved October 8, 2015, from Operation Enduring Freedom Afghanistan: http//www.iCasualties.org

ICR. (2013). Retrieved october 25, 2015, from crises: http://www.responsibility toprotect.org/index.php/crises/crisis-insyria

Independent News. (2013). Retrieved october 25, 2015, from Politics: http://www.independent.co.uk/news/uk /politics/david-camerons-plans-formilitary-action-in-syria-shot-down-indramatic-commons-vote-8788612.html

Islam Times. (2014). Retrieved March 20, 2015, from Syria: http://islamtimes.org/ vdcaw6nea49nwi1.h8k4.txt

Journalist Resource. (2013). Retrieved october 25, 2015, from Security Military: http://journalistsresource.org/studies/go vernment/security-military/us-militarycasualty-statistics-costs-war-iraqafghanistan-post-911

Kementerian Pertahanan. (2014). Retrieved september 20, 2015, from Files:

http://www.kemhan.go.id/kemhan/files/ 4b6d.pdf

Kompas. (2013, March 20). Retrieved November 25, 2015, from International: http://internasional.kompas.com/read/2 013/03/20/14334227/Biaya.Perang.AS.Jad i.Beban.Selama.100.Tahun 
Jurnal Administrasi Negara

ISSN : 2598-4039 (Online)

ISSN : 2302-2231 (Print)

\section{Syuryansyah, Andrialius Feraera \\ Universitas Serang Raya}

Kompasiana. (2013, september 08). Retrieved March 20, 2015, from Hankam:

Kompashttp://hankam.kompasiana.com /2013/09/08/serangan-ke-suriah-antaragengsi-dan-khawatir-589786.html

Military Factory. (2014). Retrieved October 8, 2015, from Vietnam Casualties:

http://www.militaryfactory.com/vietna $\mathrm{m} /$ casualties.asp diakses pada 8 Oktober 2015

Moslem Info. (2013). Retrieved October 01, 2015, from Dunia Islam: http//www.mosleminfo.com

National Priorities. (2014). Retrieved october 25, 2015, from Cost Military Intervention in Syria: https://www. nationalpriorities.org/blog/2014/05/05/co st-military-intervention-syria/

New Yorker News. (2013). Retrieved september 20, 2015, from News, could obama diplomacy lead to war: http://www.newyorker.com/news/dailycomment/could-obamas-syriadiplomacy-lead-to-war

News Week. (2014). Retrieved october 25, 2015, from ISIS Enemy: http://www.newsweek.com/2014/09/19/i siss-enemy-list-10-reasons-islamic-statedoomed-268953.htm

Nye, J. (2003). Propaganda Isn't the Way: Soft Power. International Herald Tribune.

Nye, J. (2004). Soft Power: The Means to Success in World Politics. Public Affairs.

Politic Geography. (2013, March). Retrieved March 20, 2015, from Syria Uprising:

http://www.polgeonow.com/2013/03/syr ia-uprising-map-march-2013-9Syria.

2013.

Public Broadcasting Service. (2013, september). Retrieved september 20, 2015, from News Hour: http://www.pbs.org/newshour/extra/201 3/09/u-s-makes-case-military-actionsyria/

Reuters. (2013). Retrieved october 25, 2015, from Article: http://www.reuters. com/article/2013/09/03/us-syria-crisisusa-idUSBRE97T0NB2013090

Rumelt, R. P. (2011). Good Strategy/Bad Strategy. Crown Business.

S.Nye, J. (1990). Bound to Lead: The Changing Nature of American Power. New York: Basic Book. 
Jurnal Administrasi Negara

ISSN : 2598-4039 (Online)

ISSN : 2302-2231 (Print)

\section{Syuryansyah, Andrialius Feraera \\ Universitas Serang Raya}

S.Nye, J. (2011). The Future of Power. New York: Public Affairs.

Sindo News . (2013). Retrieved October 01, 2015, from International: http//www.international.sindonews.co $\mathrm{m} / \mathrm{read} / 806166$

Telegraph. (2013). Retrieved october 25, 2015, from News: http://www.telegraph.co.uk/news/world news/middleeast/syria/10275158/Syriacrisis-No-to-war-blow-to-Cameron.html

The Atlantic. (2014). Retrieved october 25, 2015, from International: http://www.theatlantic.com/internationa 1/archive/2014/11/300000-an-hour-thecost-of-fighting-isis/382649/

The Fiscal Times. (2014). Retrieved october 25, 2015, from New US price Tag War: http://www.thefiscal times.com/2014/10/10/New-US-PriceTag-War-Against-ISIS-40-Billion-Year

The Guardian. (2013, september 11). Retrieved september 20, 2015, from World:

http://www.theguardian.com/world/201 3/sep/11/obama-diplomatic-path-syriachemical-weapons

The Guardian. (2013). Retrieved october 25, 2015, from World: http://www. theguardian.com/world/2013/aug/26/syr ia-crisis-international-viewsintervention

The Guardian. (2015). Retrieved october 25, 2015, from syria kurds isis turkey civil war: http://www.theguardian.com/world/201 5/aug/01/syria-kurds-isis-turkey-civilwar

The Verge. (2013). Retrieved October 25, 2015, from http://www.theverge. com/2013/9/13/4726390/disarming-syriaassad-chemical-weapons-may-requireboots-on-the-ground

The Wall Street Journal. (2014). Retrieved october 25, 2015, from 2015 Budget: http://blogs.wsj.com/washwire/2014/03/ 04/2015-budget-syrian-crisis-a-focus-ofu-s-diplomatic-spending/

Time News. (2013). Retrieved october 25, 2015, from http://swampland. time.com/2013/09/09/mal-shaping-thesyrian-battlefield/

Time News. (2014). Retrieved October 8, 2015, from Afghanistan War Cost: http://ime.com/3651697/afghanistanwar-cost/ diakses pada 8 Oktober 2015

Union County College . (2013). Retrieved March 29, 2015, from Decision Making 
Jurnal Administrasi Negara

ISSN : 2598-4039 (Online)

ISSN : 2302-2231 (Print)

\author{
Syuryansyah, Andrialius Feraera \\ Universitas Serang Raya
}

Models:

http://faculty.ucc.edu/egh/decision mak ing models.html

US Department of State. (2014). Retrieved september 20, 2015, from Organizations Documents:

http://www.state.gov/documents/organi zation/220588.pdf

USNI News. (2013). Retrieved october 25, 2015, from http://news.usni.org/2013/04/22/syrianintervention-some-pros-mostly-cons

VoA . (2013, September 01). Retrieved March 20, 2015, from Amerika Serikat Membatalkan Serangan Militer ke Suriah: http://www.voaislam.com/read/world-

world/2013/09/01/26582/amerikaserikat-membatalkan-serangan-militerke-suriah/\#sthash.wWuQce7i.dpuf

Washington Post. (2013). Retrieved october 25, 2015, from National Security: https://www.washingtonpost.com/worl d/national-security/cia-ramping-upcovert-training-program-for-moderatesyrian-rebels/2013/10/02/a0bba084-2af611e3-8ade-a1f23cda135e_story.html

Washington Post. (2013). Retrieved october 25, 2015, from Where the votes stand on syria: http://www. washingtonpost.com/blogs/the-fix/wp/ 2013/09/02/where-the-votes-stand-onsyria/

Washington Post. (2013). Retrieved october 25, 2015, from World: https://www.washingtonpost.com/worl $\mathrm{d} /$ national-security/cia-ramping-upcovert-training-program-for-moderatesyrian-rebels/2013/10/02/a0bba084-2af611e3-8ade-a1f23cda135e_story.html

Weekly Standard. (2013). Retrieved september 20, 2015, from Between Hard and Soft Power: http://www. weeklystandard.com/articles/betweenha rdandsoftpower.html

White House. (2013, september 14). Retrieved september 20, 2015, from The Press Office: https://www.white house.gov/the-press-office/2013/09/14/ weekly-address-pursuing-diplomaticsolution-syria

World Time. (2013). Retrieved october 25, 2015, from Death toll in syria: http://world.time.com/2013/10/01/group -says-syria-death-toll-at-115000/ 